\title{
When the Subaltern Speaks: Race and Gender in Selected Works by ZadieSmith and LeilaAboulela
}

\section{Dr. Sally Emam*}

\section{SSS_emam@yahoo.com}

\section{Abstract}

This thesis which is entitled "When The Subaltern Speaks: Race and Gender in Selected Works by Zadie Smith and Leila Aboulela" tackles the notion of the subaltern in the contemporary British novel and attempts a comparison between various forms of subalterns. It deals with various cultural theorists who speak about the limits within which the subaltern woman writer is allowed to speak. It is within this perspective that selected works by the black British novelist Zadie Smith and the Sudanese Muslim novelist Leila Aboulela are considered. The two novelists are deemed two case studies because they are clear examples of subaltern women who are able to speak or to make their voices heard in the contemporary literary scene in Britain. More important is that their contributions are placed within the context of the transformations taking place in British culture and society today.

Both Smith and Aboulela share the experience of being black and not belonging to the centre. They both live in England and write in English. Despite coming from different

* مدرس بالمتطلبات الجامعية، قسم اللغة الإنجليزية، جامعة مصر للعلوم والتكنولوجيا. 
backgrounds, they both share the optimistic attitude in relation to coexistence and tolerance. The subalternity of their characters is set against the background of race and/or gender. However, the considerable advancement in the status of women makes the question of gender subsumed to the question of race. That is why in Smith and Aboulela's novels, women are no longer the oppressed or the victimized gender. The female characters are deemed subalterns just like their male counterparts.

Smith and Aboulela are among the subaltern writers who stand centre stage without the risk of being marginalized. They belong to the new generation of English writers whose narratives represent a new form of fiction capable of responding to a world of changing values. If Smith and Aboulela have been able to speak, each using her own distinguished voice to express her message, they have also managed to give their subaltern characters a voice with which they can speak and challenge the previous silencing and denial.

The thesis is divided into three chapters with an introduction and a conclusion. Chapter One which is entitled "The Unique Specificity of Double-Otherness" provides the theoretical framework of the study. In analyzing the notion of the subaltern, the chapter tackles the postcolonial theory clearly manifested in the novels and underlines the connection between race and gender. It sheds light on the different categories of subalterns and discusses the various opinions of cultural theorists, among whom are Spivak and 
Bhabha, who stress the limits within which the subaltern is allowed to speak. Their diverse manifestations of subalternity and relevant concepts such as mimicry, hybridity, neocolonialism and the representation of the ex-colonized help in establishing the context within which the analyses of the novels are framed.

Chapter Two which is entitled "Zadie Smith: A Literary Representative of a New Britain" is a study of the black British novelist Zadie Smith who belongs to the category of the British-born writers from other ethnic backgrounds. Smith's selected novels, White Teeth and On Beauty, depict a new cultural model which is unrelated to previous confrontational models of multiethnic London. The two novels attempt to bridge the gaps between races, cultures and religions through the fusion of all of them in one pot. In her novels, Smith employs cultural differences and clashes to arrive at acceptance and tolerance. She presents racism as nonsense and treats it comically. The theme of the immigrant's attitude to home is also addressed, and the legacy of dislocation and belonging is highlighted. Smith stresses the inescapability of history and the role played by roots and origins. Difficulties of familial relationships are represented through generational as well as gender conflict.

Chapter Three which is entitled "Muslim Immigrant Writing: Leila Aboulela as a Case Study" is a study of the Sudanese Muslim novelist Leila Aboulela. Living in England and writing in English, Aboulela writes a fiction that is motivated by a sense of geographical and cultural displacement. Aboulela's selected novels, The Translator and 
Minaret, embody the conflict between East and West and focus on the possibility of achieving a meaningful relationship between both of them. The two novels offer a different portrayal of Muslim women in London who seek emotional comfort in their growing religious identity. Their success is conditioned by their ability to coexist with others without losing their Islamic identity. In her novels, Aboulela treats racism lightly as if it does not exist to alleviate the bitterness of the "us" versus "them" legacy. She also delineates multicultural London highlighting the coexistence of tradition and modernity. The question of home and exile is raised - whether home is a geographical or an emotional entity where one feels a sense of belonging. Gender relations and generational conflicts are also foregrounded.

In short, this thesis argues that the subaltern can speak and postulates that Spivak's insistence on the speechlessness of the subaltern is by no means a final say. Subaltern writers as well as subaltern characters have gained a status that they had been previously denied. Silenced migrants and minorities have acquired the power of speech and have developed the capability of transformation.

\begin{abstract}
Keywords: Postcolonialism - Multiculturalism - Racial discrimination - Gender discrimination - Subalternity and minority.
\end{abstract}




\section{مستخلص}

هذه الرسالة وعنوانها: "عندما يتكلم التابع: الانتماء العرقي والجنسي في أعمال مختارة لزادى سميث Zadie Smith وليلى ابوالعلا Leila Aboulela " تتناول مفهوم التابع في الرواية البريطانية المعاصـرة مع مقارنـة الأنماط المختلفة ممن ينطبق عليهم هذا المفهوم. كمـا تتـاول العديد من واضـعي النظريـات الثقافيـة الذين تحدثوا عن الكاتبات التابعات والمساحة المسموحة لهن للتعبير وفى هذا الإطار يتم تتاول أعمال مختارة لكل من الكاتبة الروائية البريطانية السمراء زادى Leila والكاتبة الروائية السودانية المسلمة ليلى ابوالعلا Zadie Smith سميث فقد استطاعت كل من الكاتبتين التعبير عن أنفسهما في المشهر الأدبـي في بريطانيا ووضـع نتاجهما الأدبـي في إطـار التحولات المستمرة في المجتمع الثقافي البريطاني. تتشارك كل من زادى سميث Zadie Smith وليلى ابوالعلا Leila Aboulela في إنهما من الكاتبات التابعات اللاتي يعشن في انجلترا ويكتبن باللغة الانجليزية. وبالرغم من انتمائهما لخلفيات ثقافية مختلفة إلا إنهما لديهما نفس التفاؤل فيما يتعلق بالقدرة على التعايش والتسامح. وبالرغم من أن المفترض أن الثخصيات النسائية الموجودة في رواياتهما تعاني من التبعية بسبب العنصـر والنـوع إلا أن التقدم الملحـوظ في وضـع المـرأة يجعل التركيز ينصب فقط على العنصر ولهذا فإن الشخصيات النسائية في الروايات لا تعاني من التهميش بسبب النوع وإنمـا تتلقى نفس المعالجـة التي تتلقاهـا الثخصيات

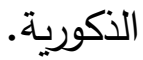


Leila Aboulela وليلى ابوالعلا Zadie Smith ونلا من زادى سميث ينتميان إلى جيل جديد من الكتاب الذين تعبر أعمالهم عن عالم يتميز بتغير قيمه. وكما استطاعت الكاتبتان التعبير بالكتابة فقد أعطوا شخصياتهم الروائية القدرة على التعبير الذي يخالف الصمت والتهميش الذي عانوا منه طويلا فيما مضىى.

\section{تنقسم الرسالة الى ثلاثة فصول ومقدمة وخاتمة.:}

الفصل الأول وعنوانه: "الخصوصية الفريدة لازدواجية مفهوم الآخر" يقدم الإطار النظري للدراسة. فيقوم بتحليل مفهوم التابع ونظريـة ما بعد الاستعمار المطبقة على الروايات كما يلقى الضوء على العلاقة بين العنصر والنوع ويحلل الآراء النقدية لواضـي النظريـات الثقافية من أمثال سبيفك Spivak وبابا Bhabha فالتتاول المتنوع لمفهوم التبعية وبعض المفاهيم المتعلقة به مثل التهجين الثقافي والاستعمار الجديد يحدد السياق الذي يتم تحليل الروايات في إطاره. الفصل الثاني وعنوانـه: " زادى سميث Zadie Smith: أحد الأمثلة الأدبية لبريطانيا الجديدة " يعد دراسة للكاتبة الروائية زادى سميث Zadie Smith التي تتنمـي إلى الكتاب المولودين في بريطانيـا مـن جذور عرقيـة أخرى. وتعتبر الأعمال المختارة لسميث Smith وهما: White Teeth و On Beauty نموذج ثقافي جديد لا ينتمى إلى النماذج السابقة المليئة بالمواجهات فيما يتعلق بالتعددية العرقية في لندن كما تقوم بعبور الفجوات العنصرية والثقافية والدينية

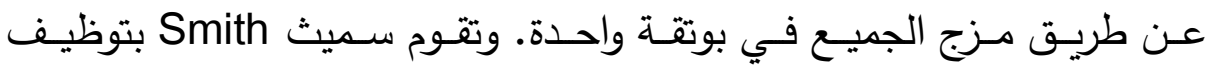


الاختلافات الثقافية والصراعات وصولا الى التعايش والتسامح كما تتتاول التمييز العنصري بطريقة ساخرة وتتناول مفهوم الوطن والانتماء ودور التاريخ والجذور وتبرز الخلافات العائلية من خلال صراعات الأجيال المختلفة وصراعات الرجل والمرأة. الفصل الثالث وعنوانه: "كتابات المسلمين المهاجرين: دراسة حالة لليلى ابوالعلا Leila Aboulela يعد دراسة للكاتبة الروائية ليلى ابوالعلا Leila Aboulela التي تعيش في انجلترا وتكتب بالإنجليزيـة وبالتـالي تعبر عن العزلة الجغرافيـة والثقافية. تصور الأعمال المختارة لليلى ابوالعلا Leila Aboulela وهما: The Translator بينهمـا فتقدم الروايـات تجسيد مختلف للمـرأة المسـلمة التي تلـوذ بملجـأ الدين ويشترط لقدرتها في التعايش مع الآخر احتفاظها بهويتها الإسلامية وتتناول ليلى ابوالعلا Leila Aboulela التمييز العنصري بأسلوب التجاهل كما لو كان لا وجود له لتخفيف حدة التوتر بين الأنا والآخر • وتصور التعددية التقافية في لندن بمنظور ايجابي يركز على التناغم بين التقليد والحداثة كما تلقى الضـوء على مفهوم الوطن والمنفى وصراعات الأجيال والأنواع. 


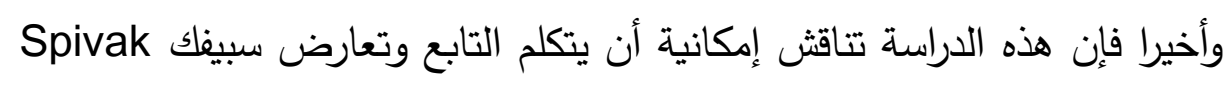

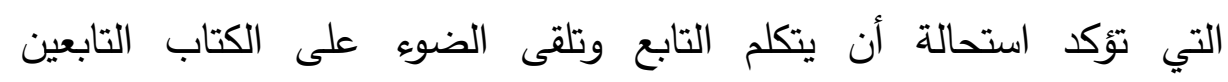

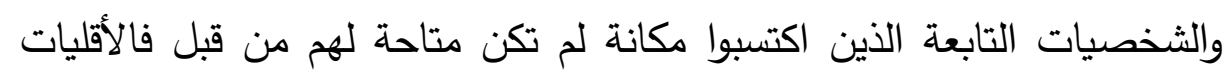

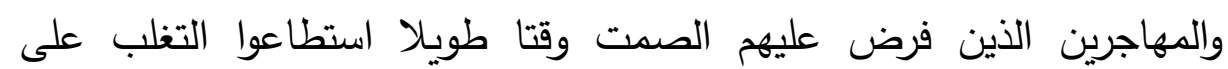
صمتهم والتعبير عن أنفسهم.

الكلمـات المفتاحية: حركـة مـا بعد الاستعمار - التعددية الثقافية - التمييز العنصري - التمييز الجنسي - التبعية والأقلية. 